\title{
Heterogeneity and Competitiveness of Entrepreneurial Processes in the European Union with Special Attention on Croatia as Candidate Country
}

Ksenja Pušnik, Maks Tajnikar *

Abstract:

The paper investigates the efficiency of entrepreneurial processes in European Union member states and Croatia as a European Union candidate country. The authors follow the model of Davidsson (2004), who argues that entrepreneurial activity originates in three waves: the wave of ability, need and opportunity for entrepreneurship; the wave of perceptive ability, perceptive need and perceptive opportunity for entrepreneurship; and entrepreneurial motivation and activity. The authors of the paper argue that the efficiency of the transformations of one entrepreneurship wave to another can be measured by Data Envelopment Analysis (DEA) on the basis of the Global Entrepreneurship Monitor database, which is a new approach to the analysis of entrepreneurial processes. The results indicate high level of heterogeneity of entrepreneurial processes among European Union member states. The authors give special attention to Croatia and conclude that the membership of Croatia in European Union would not threaten the entrepreneurial processes of this European Union candidate country.

Keywords: heterogeneity, competition, entrepreneurial processes, efficiency, data envelopment analysis (DEA), European Union, Croatia, Global Entrepreneurship Monitor

JEL: L26, O10

DOI: $10.2478 / v 10033-010-0001-8$

\section{Introduction}

Two conditions have to be fulfilled in order for the integration of economies into a united economic area to become successful. First, there must not be too many differences in development, economic system and economic policy across economies. Economies cannot differ in their development, economic system and economic policy too much. This allows that economic processes across countries are alike and that those processes of a particular country could be integrated into a united economic area. Second, economies have to preserve their particularities, which make them competitive in the united economic area. Those principles are decisive also for the successful formation of a single market area in Europe in the form of the entrance of new member countries into the European Union, and in the form of the entrance of new member countries into the European Monetary System in particular.
In this paper, the authors are interested in economic processes in the field of entrepreneurship. Therefore, the aim of the paper is to present: i) to what extent the economic processes in the field of entrepreneurship, i.e. entrepreneurial processes, are harmonized across the European Union member states, ii) the variations in those
Ksenja Pušnik
Faculty of Economics and Business,
University of Maribor
e-mail: ksenja.pusnik@uni-mb.si
Maks Tajnikar
Faculty of Economics,
University of Ljubljana
e-mail: maks.tajnikar@ef.uni-lj.si 
processes across countries, and iii) what influences membership in the European Union can have on entrepreneurial processes in new member states. Special attention is given to Croatia as a candidate country of the European Union. The aim of the paper is, therefore, not to investigate country differences in determinants of entrepreneurship processes in the European Union, but to investigate the level of heterogeneity of entrepreneurial processes among European Union countries and its influence on the entrance of new member countries into the European Union.

From this perspective, we measure the "efficiency" of the transformation of one of the three waves of entrepreneurial processes into another in a particular country. In particular, we use Davidsson's (2004) model of entrepreneurship processes to measure: (i) the efficiency of the transformation of objective determinants of entrepreneurship (i.e. objective ability, need and opportunity for entrepreneurship in a particular country) into perceptive determinants of entrepreneurship (i.e. the perception of individuals of their ability, need and opportunity for entrepreneurship), and ii) the efficiency of the transformation of perceptive determinants of entrepreneurship into entrepreneurial motivation, which transform into entrepreneurial activity. We adopt the Data Envelopment Analysis (DEA) model to measure the efficiency of the above transformations, which is, to our knowledge, a new approach to the analysis of entrepreneurship. The results reveal the level of heterogeneity in entrepreneurial processes among observed countries.

In light of the triggering question, "Are economic processes in the field of entrepreneurship among countries alike?" the analysis in this paper was performed on a cross-country level and was based on the characteristics of the economies of European Union member countries and of Croatia that are important for entrepreneurship, as well as using the Global Entrepreneurship Monitor (GEM) Research data base. The selection of countries was based on the availability of data. The main selection criterion was the participation of countries in the GEM research project, which is a multinational research program, aimed at describing and analyzing the entrepreneurial process in its early stages (the start-up phase) within a wide range of countries. It began in 1998 and has, since then, provided a very rich database of early-stage entrepreneurship. The following European Union member states participated in GEM research in 2004 and 2006: Belgium, Denmark, Finland,
France, Germany, Greece, Hungary, Ireland, Italy, the Netherlands, Slovenia, Spain, Sweden, and the United Kingdom.

This paper attempts to make three main contributions to the literature. The first is to introduce the concept of economic efficiency into analyses of entrepreneurial processes. This is to our knowledge an original approach to the analysis of entrepreneurial processes, since no research so far has investigatied entrepreneurship processes using this methodology. The second is to provide empirical investigation of the entrepreneurial processes' model developed by Davidsson (2004). The third is to enhance our understanding of differences in the entrepreneurial processes across European countries. An important part of entrepreneurship research investigates determinants of entrepreneurship, also across European countries, yet there has been no empirical research that investigated how efficient those countries are in transforming determinants of entrepreneurship, which have been proven to impact level of entrepreneurship, into entrepreneurial activity. The main supposition of the paper is the following: Entrepreneurial processes can be measured with measures of economic efficiency, in particularly with Data Envelopment Analysis. This allow for identifying differences in entrepreneurial processes across countries.

The paper is organized as follows. First, we discuss the relevant theoretical and empirical literature. The following section offers some new thoughts regarding entrepreneurial processes and its determinants by measuring the efficiency of transformations among the three waves of entrepreneurship across GEM countries. The model of entrepreneurial processes and hypothesis are specified. Next, we present the results of our analysis, and, finally, discuss conclusions.

\section{Theoretical and Empirical Background}

\subsection{The models of entrepreneurial processes}

In this paper, the authors follow the stylized findings of Davidsson (2004), which from the entrepreneurship determinants point of view indicate that entrepreneurial activity originates in three waves. The first wave is composed of ability, need and opportunity for entrepreneurship, which are objective determinants in a particular economy. This wave is then transformed into the second wave, which are perceptual determinants, composed of perceptive ability, perceptive need, and 
perceptive opportunity for entrepreneurship. All three components of the wave of perceptual determinants are then transformed into the third wave, which are entrepreneurial motivation and entrepreneurial activity. The transformation of the wave of objective determinants to the wave of perceptual determinants and the transformation into the third wave take place in different economies in different ways.

Davidsson's approach was confirmed by Arenius and Minniti (2005), Koellinger, Minniti and Shade (2005, 2007, 2008) and Koellinger and Minniti (2006), whose empirical evidence showed that perceptual variables are significantly correlated with new business creation, and that nascent entrepreneurs rely significantly on subjective and often biased perceptions, rather than on objective expectations of success. More specifically, confidence in one's skills and abilities, fear of failure, knowing other entrepreneurs, and the perception of opportunity are the kinds of perceptual variables that could impact the creation of new businesses. The view that perceptual variables are significantly correlated with new business creation has its origin in early research into how an individual recognizes opportunities for business creation (Shane and Ventkataraman 2000; Eckhardt and Shane 2003; Reynolds et al. 2003) and is confirmed by several empirical findings. For example, the evidence of Minniti and Langowitz (2007) and Minniti and Nardone (2007), showed that subjective perceptual variables influence the entrepreneurial propensities of women and account for much of the difference in entrepreneurial activity between the sexes.

The ability to perceive good business opportunities is also assumed to be important for entrepreneurship (Eckhardt and Shane 2003; Shane and Venkataraman 2000; Reynolds et al. 2003). Referring to Shapero and Sokol (1982), Arenius and Kavalainen (2006) discussed the distinction between, on the one hand, actual skills (abilities) and opportunities and, on the other, the perception of skills and opportunities. It is true that there are some doubts regarding the opportunity concept (Davidsson 2003); for example, opportunity is by almost all definitions considered a favourable situation, known to be profitable. From this point of view, individuals cannot know whether or not what they pursue is an opportunity - only successful actions can, ex post facto, be marked as opportunities. Since our paper is focused particularly on start-up entrepreneurs, evaluating opportunities in a retrospective way is impossible.
Furthermore, the ability of an individual to enter into entrepreneurship and use the entrepreneurial skills, knowledge and experiences needed for it, can be regarded as a major determinant of entrepreneurship, according to literature (Davidsson 1991; Shane 2000; (Shaver and Scott 1991).

The evidence of Tajnikar and Pušnik (2008), who first used the model of Davidsson (2004) to investigate the determinants of Entrepreneurship in Slovenia and other countries participating in the Global Entrepreneurship Monitor (GEM) research in 2004, show that (i) strong perceptions of ability for entrepreneurship are linked to a high percentage of the population capable of entrepreneurial activity i.e., population aged between 1864 years and male, (ii) strong perceptions of the need for entrepreneurship are related to high unemployment and high income disparity, and (iii) strong perceptions of opportunity for entrepreneurship are determined by high expenditures on $R \& D$ and innovation and on the transfer of R\&D from universities to firms. In all the countries investigated, the level of nascent entrepreneurship should have been higher with regard to observed perceptual determinants of entrepreneurship, considering countries which are the most "efficient" from an entrepreneurship point of view. It is, however, evident that, in numerous countries, high levels of migration, wages and education, as well as a prevalent service industry, do not also create high perceptions about entrepreneurship that would encourage individuals to start new businesses. Differences in efficiency between countries with regard to the transformation of perception of needs into actual entrepreneurial activity could also be explained by differences in GDP per capita, differences in the influence of perceptions on entrepreneurial activity by the GDP, and differences in the entrepreneurial culture in each country.

\subsection{Determinants of entrepreneurial processes}

The aim of the paper is to investigate how "efficient" were the transformations of one of the abovementioned waves of determinants of entrepreneurship into another. In terms of "efficiency" the authors measure also the heterogeneity of entrepreneurial processes across members of the European Union, which should not be large, in order to enable the co-existence of entrepreneurship in the single European market. The authors also intend to discover particularities of entrepreneurial processes in a particular country, which 
enables a country comparative competition advantages in a single European market. The aim of the paper is not to discover determinants of entrepreneurship but to measure the impact of determinants on entrepreneurship. Therefore, the selection of potential determinants of entrepreneurship was based on an empirical literature review. We also presume, based on the findings of previous research, that entrepreneurial processes across countries are not alike. In the following theoretical and empirical review, we, therefore, intend to present: i) to what extent researchers have identified and argued the heterogeneity of entrepreneurial processes, and ii) which determinants have proven to have significant impact on entrepreneurial processes and the direction of their impact.

The choice of entrepreneurship determinants plays a crucial role in the empirical analysis of the transformation of different waves of entrepreneurship into others presented in this paper. The authors of this paper hypothesized the influence of the entrepreneurship determinant on entrepreneurial activity and its direction on the empirical findings in the entrepreneurship literature. Following the findings of Davidsson (2004), we have to specify objectively determinants which i) express ability, need and opportunity for entrepreneurship, ii) measure individuals' perceptions of ability, need, and opportunity for entrepreneurship, and iii) measure entrepreneurial motivation and entrepreneurial activity. The choice of entrepreneurship determinants has to consider the appropriate direction of the influence of entrepreneurship determinants on entrepreneurial activity.

In general, entrepreneurship literature can be classified into two main streams: one examining the supply-side and one examining the demand-side. This distinction has been introduced by Henriquez et al. (2002) and was also made by Thurik and Grilo (2005). The demand-side literature examines, on a macro level, historically and culturally determined framework conditions, such as market sources, political and institutional frameworks etc., while the supply-side studies focus on the availability of skilled and motivated individuals to occupy entrepreneurial roles, such as the effects of human capital, norms, etc. On the demand side, technological developments-those which could be measured by an innovation index —increase competition among new businesses. Further, a strong service-sector presence in an economy is often accompanied by a high level of entrepreneurship. On the supply side, factors that influence the level of entrepreneurship refer, in large part, to the size, spread and composition of the population; population growth, density and mobility; age structure; unemployment; and immigration. Unemployment can serve as a push factor for entrepreneurship at the microlevel, while, on the macro-level, a high level of unemployment in a depressed economy can also have a negative impact on opportunities for entrepreneurship.

Other classifications of determinants of entrepreneurship can be found in the literature. While explaining regional differences in entrepreneurial activity in Germany, Sternberg (2005) classified entrepreneurial determinants into three categories: personal (e.g., gender, age, education, experience, attitudes), macrosocial environment or network (e.g. contacts with other founders, integration in personal network), and regionalcontextual (general or start-up-related conditions) (see also Sternbergand Wennekers 2005). Grilo and Thurik (2004) have proposed the Eclectic Framework of entrepreneurship, first introduced in Audretsch, Thurik, Verheul, and Wennekers (2002), in order to provide a unified framework for understanding and analyzing what determines entrepreneurship. The Eclectic Framework of entrepreneurship integrates the different strands from the relevant fields into a unifying framework. At the heart of the Eclectic Framework is the integration of factors shaping the demand for entrepreneurship on the one hand, with those influencing the supply of entrepreneurs on the other (Grilo and Thurik 2005a, p. 2).

While using the Eclectic framework, Grilo and Thurik (2004; see also Grilo and Thurik 2005b and 2008) investigated the influence of demographic variables such as gender, age and education level, a set of explanatory variables, which includes the perception by respondents of administrative complexities, of the availability of financial support, a rough measure of risk tolerance, the respondents' preference to be self-employed and country specific effects on various entrepreneurial engagement levels using survey data from the 15 EU member states, Norway, Iceland, Liechtenstein and the US. The most striking result is that the perception of lack of financial support has no discriminative effect across the various levels of entrepreneurial engagement, while perception of administrative complexities plays a negative role only for high levels of engagement.

In general, determinants of entrepreneurial activity include economic as well as technological, demographic, social and cultural factors. Numerous researchers have established that, on an individual level, age, gender, race, 
education, earnings, capital assets, previous professional experience, marital status, professional status of parents, and other factors are important drivers (Douglas and Shepherd 2002; Wagner 2003; Blanchflower 2004; Grilo and Thurik 2004; Grilo and Irigoyen 2006). Furthermore, research has shown that men are more likely to be engaged in the entrepreneurship process than are women (Minniti, Arenius, and Langowitz, 2005; Arneus and Kavalainen 2006; Tominc and Rebernik 2006), and that individuals between 25 and 45 years of age are most likely to be entrepreneurs (Reynolds, Hay, and Camp 1999). Blanchflower, Oswald and Stutzer (2001) and Grilo and Irigoyen (2006) found that increased age has a generally negative influence on entrepreneurship, although Delmar and Davidsson (2000) found empirical evidence showing a positive relationship between entrepreneurship and age. Uhlaner and Thurik (2004; see also Arenius and De Clercq 2004), Blanchflower (2004) argued that this is valid in Europe while, in the US, the relationship between the level of education and the selfemployment rate is positive; the empirical evidence of Davidsson and Honig (2003) and Delmar and Davidsson (2000) also pointed to a positive relationship between entrepreneurial activity and education (see also Shane 2000; Shaver and Scott 1991). Furthermore, culture seems to be an important determinant of entrepreneurship (Hofstede et al. 2004).

The authors base their analysis on the theoretical assumption that entrepreneurial processes vary widely across countries, the reason being differences in determinants that determine the formation of entrepreneurship across countries (De Wit and Van Winden 1989; Acs, Audretsch, and Evans 1994; Blanchflower 2000; Audretsch and Thurik 2000 and 2001; Carree et al. 2002; Parker and Robson 2004), also in Europe (e.g. Noorderhaven et al. 2004; Grilo and Thurik 2004a, 2004b, 2005a, 2005b, 2008; Grilo and Irigoyen 2006). The origins and determinants of entrepreneurship span a wide spectrum of theories and explanations (Kihlstrom and Laffont 1979; Barreto 1989; Brock and Evans 1989; Gavron, Cowling, Holtham, and Westall 1998; OECD 1998; Blanchtlower 2000; Carree, Van Stel, Thurik, and Wennekers 2002; Verheul et al. 2002; Blanchtlower 2004; Wennekers, Uhlaner, and Thurik 2002; Arneus and De Clercq 2004; Alvarez 2005; Arenius and Minniti 2005). However, there is no single theory of entrepreneurship, although more and more theory-driven research is emerging (Davidsson 2006).

\section{Hypothesis, Model Specification and Data}

In this paper, we were interested in whether there were country differences across European Union member states and Croatia as a European Union candidate country regarding the entrepreneurial processes. For this research question to be answered, we measured to what extent the determinants of entrepreneurship transform into entrepreneurial activity. In particular, we are interested in the following questions: i) to what extent the objective determinants of entrepreneurship, which express the ability, need and opportunity for entrepreneurship, i.e. the objective characteristics of the environment, transform into perceptual determinants of entrepreneurship, which express personal perceptions and judgements about objective determinants of actual entrepreneurship, i.e. objective ability, need and opportunity for entrepreneurship, and ii) to what extent the perceptual determinants of entrepreneurship transform into entrepreneurial motivation and entrepreneurial activity. The framework of the model and the specification of variables are presented in Figure 1. The selection of variables is based on the research findings summarized in Chapter 2. On the basis of theoretical and empirical findings on entrepreneurial processes we presume that objective determinants of entrepreneurship influence the perceptual determinants of entrepreneurship and that perceptual determinants of entrepreneurship influence entrepreneurial motivation and entrepreneurial activity. The analysis is performed on the country level. According to data availability, the following European Union countries are included in the analysis along with Croatia: Belgium, Denmark, Finland, France, Germany, Greece, Hungary, Ireland, Italy, the Netherlands, Slovenia, Spain, Sweden, and the United Kingdom.

In our study, objective abilities were measured by the percentage of the total population between 18 and 64 years of age as a proxy for the size of the population, the percentage of the male population as a proxy for the gender, and gross enrolment ratio in secondary education as the percentage of the relevant age group (the variable "secondary education"), gross enrolment ratio in post-secondary education as the percentage of the relevant age group (the variable "post-secondary education"), and public expenditure on education as a percentage of GDP as proxies of education as ability for entrepreneurship. Objective needs were measured by the GINI index as a proxy of income disparity, unemployment 


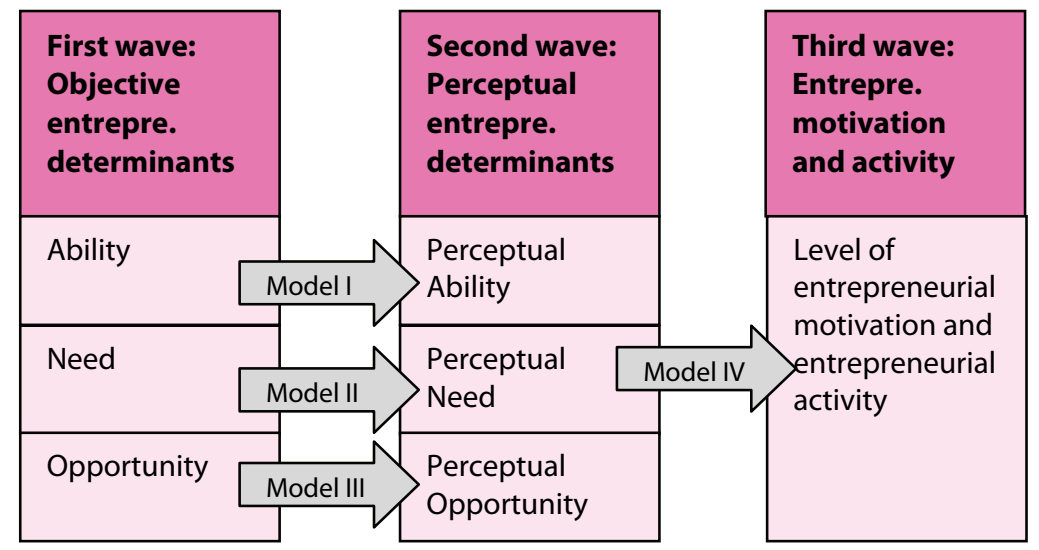

Figure 1. Models of determinants of entrepreneurship

rate as percentage of labour force, relative growth of unemployment with regard to economic growth and net migration. Objective opportunities were measured by gross domestic expenditure on $R \& D$ as a percentage of GDP, technology transfer from universities to firms, business expenditure in $R \& D$, total expenditure in $R \& D$ per capita, R\&D workers in business per capita, and trade (export plus import) to GDP ratio. Data on these objective determinants of entrepreneurship were obtained from international data sources such as the World Bank, the International Monetary Fund, the United Nations and Eurostat.

We used data on perceptive determinants of entrepreneurship, entrepreneurial motivation and entrepreneurial activity from the adult population GEM survey. This data are based upon representative samples of randomly selected adult populations, ranging from 1,000 to almost 27,000 individuals, which were surveyed in each GEM country in 2004 and 2006.

The GEM survey allowed us to identify the following perceptual variables, which make up the second wave of entrepreneurial determinants:

- Perception of ability: To measure confidence in their skills, respondents were asked whether they believe they have the knowledge, skill, and experience required to start a new business.

- Perception of need: Respondents were asked whether they believe that most people in their country would prefer that everyone had a similar standard of living.

- Perception of opportunity: Respondents were asked whether they thought that good opportunities for starting a business would exist in the area where they lived in the next six months following the survey.

The GEM survey allowed us also to identify two main motivators for entrepreneurial behaviour: wanting to exploit a perceived business opportunity (opportunity entrepreneurs) and being pushed into entrepreneurship because all other options for work are either absent or unsatisfactory (necessity entrepreneurs). The GEM identified both groups by asking all respondents involved in entrepreneurial activity whether they were involved because of a business opportunity or because they had no better employment alternative. The first motive was measured by the Opportunity TEA Index, where opportunity is the major motive (number of adults 18-64 years old per 100 involved in opportunity entrepreneurship through a nascent firm or new firm or both). The second motive was measured by the Necessity TEA Index, where necessity is a major motive (number of adults 18-64 years old per 100 involved in necessity entrepreneurship through a nascent firm or new firm or both).

The GEM estimates the entrepreneurial activity as overall level of involvement in early-stage entrepreneurial activity by calculating the total entrepreneurial activity (TEA) index as the sum of nascent entrepreneurs (people in the process of starting a new business) and new business owners. We used the TEA index as the variable for entrepreneurial activity in observed countries, so the prevalence rates of early-stage entrepreneurial activity in each country were equal to the sum of nascent entrepreneurs (those individuals between 18 and 64 years of age who have taken some actions to create new businesses) and new businesses (owner-managers of firms who have paid wages for more than three months and fewer than 42 months).

The efficiency of transformation of objective determinants of entrepreneurship to perceptive determinants, and the transformation of perceptive determinants into entrepreneurial motivation and entrepreneurial activity were measured by the nonparametric linear programming method Data Envelopment Analysis (DEA) (e.g., Zhu 2003; Daraio and Simar 2007; Fried, Lovell, and Schmidt 2008; Thanassoulis, Portela and Despić 2008). In this paper, constant returns to scale (CRS) input-oriented DEA models were applied, because we are interested in how much of the inputs (objective characteristics of) a particular country has to possess in order to achieve a certain level of perceptions about abilities, opportunities and need for entrepreneurship, and how much of the inputs (perceptions) a particular country has to possess in order 
to achieve a certain level of entrepreneurial activity, respectively. Our study's research questions lead us to measure only technical inefficiency and not also cost efficiency.

Since DEA is a nonparametric linear programming method that examines the relationship between the analyzed process's inputs and outputs, we specified four models (see Figure 1). Each model presents one part of entrepreneurial processes. Models I-III estimate the transformation efficiency of the first wave of entrepreneurship determinants into the second wave. The input variables of these models are indicators of objective determinants of entrepreneurship (i.e. objective ability in Model I, objective need in Model II and objective opportunity in Model III), while the output variables are the indicators of perceptual determinants of entrepreneurship (i.e. perceptive ability in Model I, perceptive need in Model II and perceptive opportunity in Model III). Model IV assesses the transformation efficiency of the second wave of determinants into entrepreneurial activity and motivation. In this model, input variables are indicators of perceptual determinants of entrepreneurship, while output variables are indicators of entrepreneurial motivation and entrepreneurial activity.

Empirical research was limited by the availability of data and the limitations of the DEA method. As we have mentioned above, the selection of country and variables depended particularly on the GEM data source and also on the availability of other data sources. The main disadvantage of the DEA

\begin{tabular}{|l|r|r|r|r|r|}
\hline & \multicolumn{3}{|c|}{$\begin{array}{c}\text { Transformation from first wave of } \\
\text { determinants into second wave }\end{array}$} & $\begin{array}{c}\text { Transformation } \\
\text { from second } \\
\text { wave into third } \\
\text { wave }\end{array}$ & $\begin{array}{c}\text { Average } \\
\text { rank }\end{array}$ \\
\cline { 2 - 6 } & $\begin{array}{c}\text { Ability } \\
\text { Model I }\end{array}$ & $\begin{array}{c}\text { Need } \\
\text { Model II }\end{array}$ & $\begin{array}{c}\text { Opportunity } \\
\text { Model III }\end{array}$ & $\begin{array}{c}\text { TEA index } \\
\text { Model IV }\end{array}$ & \\
\hline Ireland & 0,999 & 1,000 & 1,000 & 1,000 & 1,000 \\
\hline Greece & 1,000 & 0,817 & 1,000 & 0,915 & 0,933 \\
\hline Croatia & 1,000 & 0,799 & 1,000 & 0,891 & 0,922 \\
\hline Spain & 0,802 & 1,000 & 1,000 & 0,787 & 0,897 \\
\hline Denmark & 0,761 & 0,773 & 0,892 & 0,949 & 0,844 \\
\hline United Kingdom & 1,000 & 0,534 & 0,824 & 1,000 & 0,839 \\
\hline Netherlands & 0,739 & 1,000 & 0,686 & 0,847 & 0,818 \\
\hline Hungary & 0,464 & 1,000 & 0,710 & 1,000 & 0,793 \\
\hline France & 0,696 & 1,000 & 0,475 & 1,000 & 0,793 \\
\hline Slovenia & 0,807 & 0,939 & 1,000 & 0,398 & 0,786 \\
\hline Italy & 0,663 & 0,864 & 0,798 & 0,703 & 0,757 \\
\hline Belgium & 0,763 & 1,000 & 0,684 & 0,539 & 0,746 \\
\hline Sweden & 0,788 & 0,883 & 0,647 & 0,605 & 0,731 \\
\hline Germany & 1,000 & 0,673 & 0,248 & 1,000 & 0,730 \\
\hline Finland & 0,670 & 0,609 & 0,597 & 0,973 & 0,712 \\
\hline
\end{tabular}

Source: Own calculations.

Table 1: Transformation efficiency of entrepreneurship determinants' waves of selected European GEM countries in 2004.

\begin{tabular}{|c|c|c|c|c|c|}
\hline & \multicolumn{3}{|c|}{$\begin{array}{l}\text { Transformation from first wave of } \\
\text { determinants into second wave }\end{array}$} & \multirow{2}{*}{$\begin{array}{c}\text { Transformation } \\
\text { from second } \\
\text { wave into third } \\
\text { wave } \\
\text { TEA index } \\
\text { Model IV }\end{array}$} & \multirow[b]{2}{*}{$\begin{array}{l}\text { Average } \\
\text { rank }\end{array}$} \\
\hline & $\begin{array}{l}\text { Ability } \\
\text { Model I }\end{array}$ & $\begin{array}{l}\text { Need } \\
\text { Model II }\end{array}$ & $\begin{array}{l}\text { Opportunity } \\
\text { Model III }\end{array}$ & & \\
\hline Spain & 0,814 & 1,000 & 1,000 & 1,000 & 0,953 \\
\hline Croatia & 1,000 & 1,000 & 1,000 & 0,793 & 0,948 \\
\hline Ireland & 0,877 & 1,000 & 0,915 & 1,000 & 0,948 \\
\hline Slovenia & 0,811 & 1,000 & 0,854 & 1,000 & 0,916 \\
\hline Greece & 0,837 & 0,741 & 0,972 & 1,000 & 0,887 \\
\hline United Kingdom & 0,862 & 0,689 & 1,000 & 0,968 & 0,880 \\
\hline Hungary & 0,749 & 0,980 & 0,790 & 1,000 & 0,880 \\
\hline Denmark & 0,635 & 0,804 & 1,000 & 1,000 & 0,860 \\
\hline Netherlands & 0,639 & 1,000 & 0,772 & 0,917 & 0,832 \\
\hline Finland & 0,632 & 0,671 & 1,000 & 1,000 & 0,826 \\
\hline France & 0,591 & 1,000 & 0,583 & 0,911 & 0,771 \\
\hline Sweden & 0,742 & 0,829 & 0,766 & 0,633 & 0,742 \\
\hline Italy & 0,764 & 0,875 & 0,769 & 0,474 & 0,720 \\
\hline Germany & 0,676 & 0,766 & 0,401 & 0,997 & 0,710 \\
\hline Belgium & 0,606 & 0,664 & 0,312 & 0,599 & 0,545 \\
\hline
\end{tabular}

Source: Own calculations.

Table 3 Transformation efficiency of entrepreneurship determinants' waves of selected European GEM countries in 2006. 


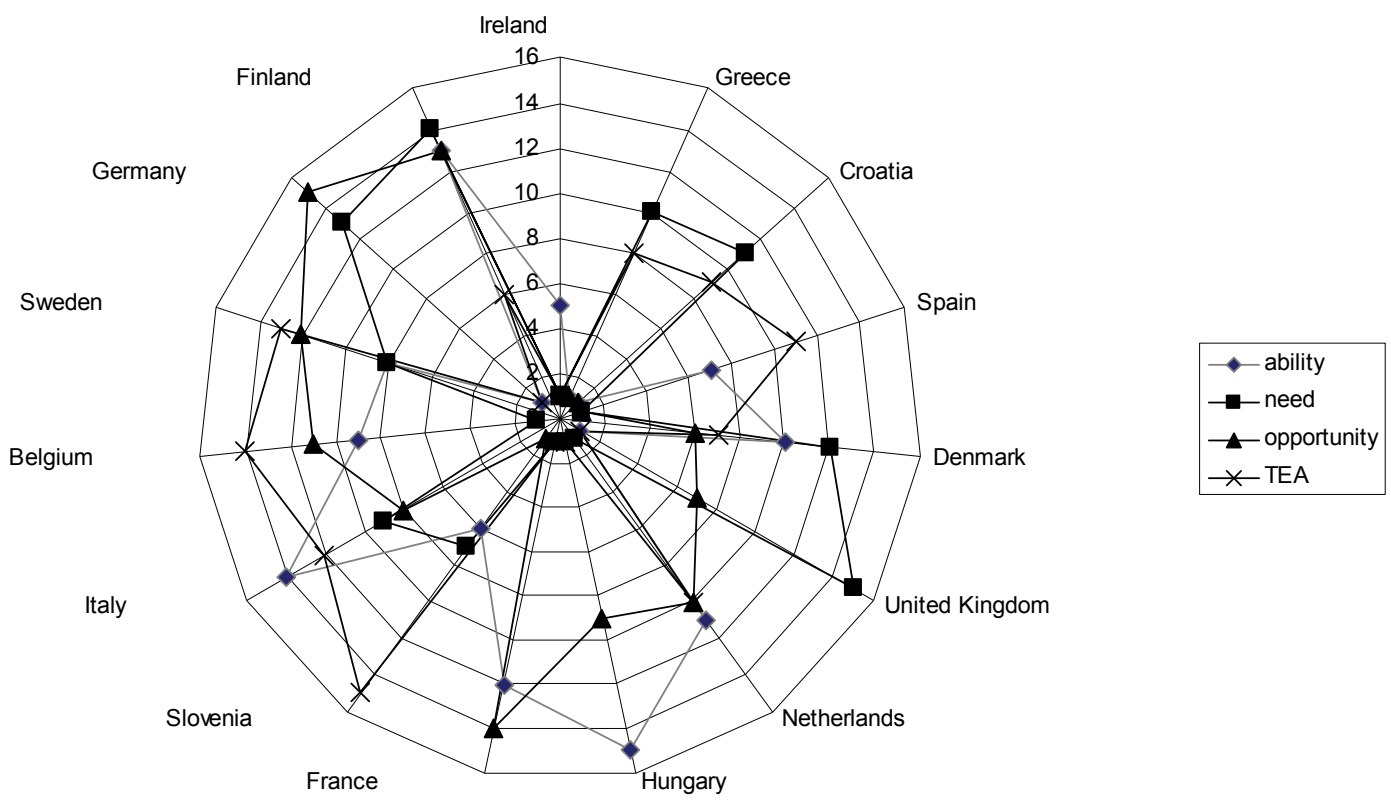

Source: Table 2, own calculation.

Figure 2: Ranking of selected European GEM countries according to transformation efficiency of entrepreneurship determinants' waves in 2004.

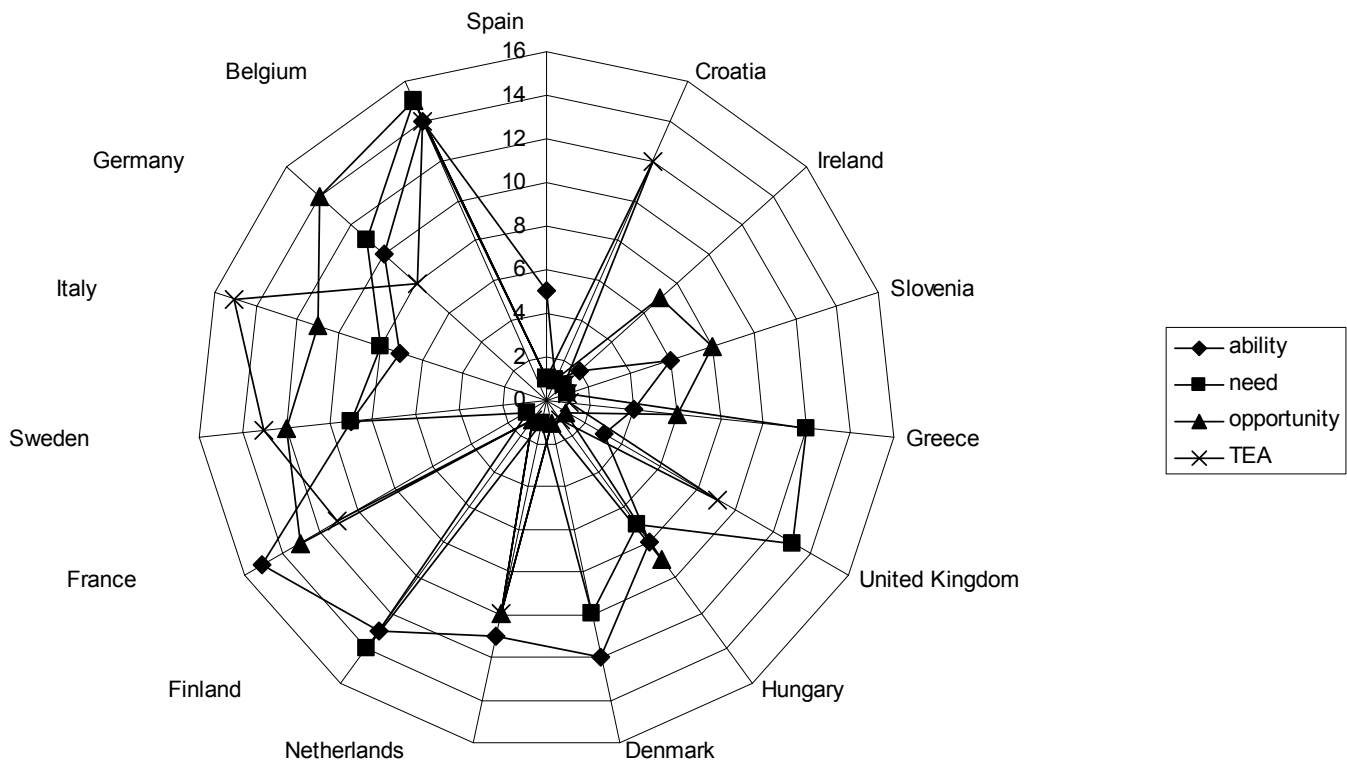

Source: Table 3, own calculation.

Figure 3. Ranking of selected European GEM countries according to transformation efficiency of entrepreneurship determinants' waves in 2006.

model is its sensitivity with regard to heterogeneity among investigated units, i.e. countries. These limitations have to be considered in the interpretation of the results.

\section{Results}

The efficiency of transformations of one wave of entrepreneurship into another among the selected countries in 2004 and 2006 are presented Table 1 and Table 2, respectively. Efficiency scores range from 0 to 1 , where efficiency scores of 1 indicate that a country is the most efficient in transforming a particular wave of entrepreneurship relative to another country in the sample, while an efficiency score of 0 indicates that a particular country is inefficient. For example, the efficiency score of Denmark in Column "Ability" in Table 1 
shows that this country would create the same level of perceptual ability only with 76 percent of the values of objective ability for entrepreneurship if this determinant of entrepreneurship influenced the creation of perceptions about the ability for entrepreneurship in this country in the same way and to the same extent as in one of the following countries: Greece, Great Britain, Germany or Croatia. The transformation efficiency of objective ability into the perceptive ability of Denmark lagged behind those countries by an average of 34 percent.

On the basis of the results presented in Table 1 in Table 2, we ranked countries according to efficiency in transforming determinants of entrepreneurship waves into each other in selected European GEM countries. The efficiency ranking is presented in Figures 2 and 3.

\section{Conclusions and Discussion}

The results of the analysis allow as to conclude that the European countries can be classified into four groups according to the characteristics of entrepreneurial processes, which indicates the large heterogeneity of entrepreneurial processes across countries of the European Union. The first group is composed of countries that are efficient both in transformation of the objective circumstances that are important for entrepreneurship into perceptions about abilities, needs and opportunities for entrepreneurship and in the transformation of those perceptions into entrepreneurial activity. In those countries, objective circumstances create strong perceptions about abilities, needs and opportunities for entrepreneurship, which are later strongly reflected in entrepreneurial activity. This group includes countries such as Ireland, Greece, Croatia, and the United Kingdom in 2004 and Spain, Ireland, and Slovenia in 2006. The second group is composed of countries where perceptions of ability, needs and opportunities for entrepreneurship are reflected in entrepreneurial activity, yet these perceptions do not grow efficiently from the objective determinants of entrepreneurship. This group is composed of countries like Slovenia, Belgium, and, Spain partly in 2004 and Croatia partly in 2006. The third group is composed of countries where the objective determinants create perceptions about entrepreneurship, but these perceptions are not efficient in leading to entrepreneurship. Included in this group are Hungary, France, Germany, Finland, Denmark partly, the Netherlands, and Italy in 2004 and France, Germany, Greece partly, the United Kingdom, Hungary, Denmark,
Netherlands, and Finland in 2006. The fourth group represents countries where individuals do not perceive objective circumstances for entrepreneurship as advantageous for entrepreneurship, and even if they did, would not actually start new businesses. Our evidence suggests that Sweden in 2004 and Belgium and partly Sweden and Italy in $\mathbf{2 0 0 6}$ are in this group.

The efficiency rankings of countries disclosed particular stability between 2004 and 2006. Many countries were in the same group in 2006 as in 2004, which indicates that the characteristics of entrepreneurial processes in a particular country were determined by factors that were not changing greatly during the analyzed period. A significant shift between groups is evident only in Greece, Belgium and the United Kingdom, which registered decreases in the efficiency of the creation of perceptions for entrepreneurship.

There is a group of countries where perceptions for entrepreneurship were reflected to a large extent in entrepreneurial activity in 2004, yet these perceptions did not grow into entrepreneurial activity efficiently. Slovenia is in this group of countries. However, in 2006 Slovenia significantly improved the creation of entrepreneurship, while in 2004 the entrepreneurial process in no other countries were similar to the entrepreneurial process in Slovenia. In 2004, the creation of perceptions for entrepreneurship was inefficient to a large extent in Finland and Germany, yet they managed to create a high level of entrepreneurship. However, there was no country in 2006 with such characteristics in its entrepreneurial process. The highest efficiency scores in creating both the perceptions for entrepreneurship and the creation of entrepreneurial activity were evident only for Ireland in 2004.

Croatia is a country with relatively efficient entrepreneurial processes. Croatia was among the most efficient countries in our sample with the most efficient entrepreneurial processes both in 2004 and 2006. Although the "efficiency" of transformation of perceptions about abilities, needs and opportunities for entrepreneurship into actual entrepreneurship activity decreased in recent years, Croatia remained among the countries with the most efficient entrepreneurial processes in general. In 2004, Croatia were relatively less efficient in creating the perception of need for entrepreneurship, yet in 2006 Croatia was among the most efficient countries also with regard to this wave of the entrepreneurial process. The interesting insight of the results is that Croatia has a unique entrepreneurial 
process, which is not similar to the entrepreneurial processes in any of the analyzed countries of the European Union. Namely, Croatia is not a benchmark for other countries in any part of entrepreneurial processes for encouraging entrepreneurial processes although it is among the most efficient countries.

The results of the efficiency of entrepreneurial process regarding the type of entrepreneurship indicate that perceptive needs were the least exploited perceptual determinants for entrepreneurship in Croatia in 2004. Namely, the level of necessity entrepreneurship should have been higher in Croatia in 2004 with regard to economic circumstances. However, in 2006 perceptions of need for entrepreneurship started to create entrepreneurial activity to a larger extent than in 2006. Therefore, Croatia was denoted by new characteristics of entrepreneurial processes in 2006, namely that perceptions about determinants of entrepreneurship create a relatively low level of opportunity entrepreneurship, where the exploitation of perceived business opportunity is a major motive for entrepreneurship.

On the basis of the results we can expect that Croatia will preserve intensive entrepreneurial processes within the single European market and that European competition will not prevent the creation of new businesses in this country. We can also conclude that entrepreneurial processes in Croatia are very specific in comparison to European Union countries, which presents certain comparative advantages for this candidate country. However, those advantages can be lost if Croatia becomes like other European Union countries with regard to entrepreneurial processes.

As we have mentioned above, the paper presents a first attempt to investigate the heterogeneity and competitiveness of entrepreneurial processes across countries empirically by adopting Davidsson's (2004) model of entrepreneurial processes and the DEA method. Possible ways of deepening and expanding the investigation of heterogeneity and competitiveness of entrepreneurial processes in European union could include the following: i) adopting second stage analysis, which would allow for the investigation of determinants of each wave of the entrepreneurial process, ii) measuring the efficiency of entrepreneurial processes' transformation by more sophisticated DEA models, and iii) using the time serial GEM data base. The development of the GEM data base would also allow for the use of more relevant indicators of some entrepreneurship determinants. ㅁ.

\section{References}

Acs, Z. J., Audretsch, D. B., Evans D. S. 1994, "The determinants of variations in self-employment rates across countries over time". Discussion paper, 871. London: Centre for Economic Policy Research.

Alvarez, S.A. (2005), Theories of Entrepreneurship: Alternative assumptions and the study of entrepreneurial action, Boston: The Essence of Knowledge.

Arenius, P. and De Clercq, D. (2004), "A network-based approach on opportunity recognition", Vlerick Leuven Gent Working Papers Series, 2004/23, Gent: Vlerick Leuven Gent management School.

Arenius, P. and Kavalainen, A. 2006. "Similarities and differences across the factors associated with women's self-employment preferences in the Nordic Countries". International Small Business Journal 24 (1): 31 - 59.

Arenius, P. and Minniti, M. 2005. "Perceptual variables and nascent entrepreneurship". Small Business Economics 24 (3): 233 - 247.

Audretsch, D. B. and Thurik, A.R. 2000. "Capitalism and democracy in the 21st century: from the managed to the entrepreneurial economy". Journal of Evolutionary Economics 10 (1): 17-34.

Audretsch, D. B. and Thurik, A. R. 2001. "What is new about the new economy: sources of growth in managed and entrepreneurial economies". Industrial and Corporate Change 10 (1): 25-48.

Audretsch, D. B., Carree, M. A. van Stel, A. J. and Thurik, A. R. 2002. "Impeded industrial restructuring: the growth penalty". Kyklos 55 (1): 8197.

Barreto, H. 1989. The entrepreneur in microeconomic theory: disappearance and explanation. New York: Routledge.

Blanchflower, D.G. 2000. "Self-employment in OECD Countries". LabourEconomics 7 (5): 471-505.

Blanchflower, D. G. 2004. "Self-employment: more may not be better". National Bureau of Economic Research Working Paper, No. 10286. National Bureau of Economic Research.

Blanchflower, D. G., Oswald, A. and Stutzer, A. 2001. "Latent entrepreneurship across Nations". European Economic Review 45: 680 691.

Brock, W. A. and Evans, D. S. 1989. "Small business economics". Small Business Economics. 1 (1): 7 - 20.

Carree, M. A., van Stel, A. J. Thurik, A. R. and Wennekers, A. R. M. 2002. Economic development and business ownership: an analysis using data of 23 OECD countries in the period 1976-1996.

Dario, C. and Simar, L. 2007. "Advanced robust and nonparametric methods in efficiency analysis: methodology and applications". In Studies in productivity and efficiency, edited by R. Färe at al., 1-248. Boston: Springer.

Davidsson, P. 1991. "Continued entrepreneurship: ability, need and opportunity as determinants of small firm growth". Journal of Business Venturing 6: 405-429.

Davidsson, P. 2006. "Nascent entrepreneurship: Empirical studies and development". Foundations and Trends in Entrepreneurship 2 (1): 1-76.

Davidsson, P. 2004. Researching entrepreneurship. Boston: Springer.

Davidsson, P. and Honig, B. 2003. "The role of social and human capital among nascent entrepreneurs". Journal of Business Venturing 18: 301-331.

Delmar, F. and Davidsson, P. 2000. "Where do they come from? Prevalence and characteristics of nascent entrepreneurs". Entrepreneurship and Regional Development 12: 1-23. 
Douglas, E. J. and Shepherd, D. A. 2002. "Self-Employment as a career choice: attitudes, entrepreneurial intentions, and utility maximization". Entrepreneurship Theory and Practice 26 (3): 81 - 90.

Eckhardt, J. and Shane, S. 2003. "The individual-opportunity nexus". In Handbook of Entrepreneurship Research, edited by Z. J. Acs and D. B. Audretsch. Dordrecht, NL: Kluwer.

Fried, H. O., Lovell, C. A. K., and Schmidt, S. S. 2008. "Efficiency and productivity". In The Measurement of Productive Efficiency and Productivity Growth, edited by H. O. Fried, C. A. K. Lovell and S. S. Schmidt, 3-91. Oxford: Oxford University Press.

Gavron, R., Cowling, M, Holtham, G. and Westall, A. 1998. The entrepreneurship society. London: Institute for Public Policy Research

Grilo, I. and Thurik, A. R. 2008. "Determinants of entrepreneurial engagement levels in Europe and the US". Industrial and Corporate Change 17 (6): 1113-1145.

Grilo, I, and Thurik, A. R. 2005a. Entrepreneurial engagement levels in the European Union, International Journal of Entrepreneurship Education 3 (2): 143-168.

Grilo, I. and Thurik, A. R. 2005b. "Latent and actual entrepreneurship in Europe and the US: some recent developments". International Entrepreneurship and Management Journal 1 (4): 441-459.

Grilo, I. and Thurik, A. R. 2001. "Determinants of entrepreneurship in Europe". In ERIM Report Series Reference No. ERS-2004-106-ORG http://ssrn.com/abstract=1265435 accessed (October 2004a, 12).

Grilo, I. and Thurik, R. 2004b. Entrepreneurship in Europe. Max Planck Institute of Economics, Papers on Entrepreneurship, Growth and Public Policy. 30 - 2004.

Grilo, I. and Irigoyen, J. M. 2006. "Entrepreneurship in the EU: To wish and not to be". Small Business Economics 26 (4): 305-318.

Henriquez, C., Verheil, I., van der Geest, I. and Bischoff, C. 2002. "Determinants of Entrepreneurship in France". In Entrepreneurship: Determinants and Policy in a European-U.S. Comparison, edited by D. B. Audretsch, R. Thurik, I. Verheul, and S. Wennekers. Economies of Science, Technology and Innovation.

Hofstede, G., Noorderhaven, N. G., Thurik, A. R., Uhlaner, L. M., Wennekers, A. R. M. and Wildeman, R. E. 2004. "Culture's role in entrepreneurship: self-employment out of dissatisfaction". In Innovation, entrepre-neurship and culture: the interaction between technology, progress and economic growth, edited by J. Ulijn, T. Brown 162-203. Cheltenham, UK and Brookfield, US: Edward Elgar.

Kihlstrom, R. and Laffont, J. J. 1979. "A general equilibrium entrepreneurship theory of the firm based on risk aversion". Journal of Political Economy 87 (4): 719 - 748.

Koellinger, P. and Minniti, M. 2006. "Not for lack of trying: American entrepreneurship in black and white". Small Business Economics Journal 27 (1): 59-79.

Koellinger, P., Minniti, M. and Schade, C. 2008. "Seeing the world with different eyes: Gender differences in perceptions and the propensity to start a business". Tinbergen Institute Discussion Papers 08-035/3. Amsterdam: Tinbergen Institute.

Koellinger, P., Minniti, M. and Schade, C. 2007. "I think I can, I think I can: Overconfidence and entrepreneurial behaviour". Journal of Economic Psychology 28 (4): 502-527.

Koellinger, P., Minniti, M. and Schade, C. 2005. "I Think I Can, I Think I Can ...: A Study of Entrepreneurial Behaviour". DIW Discussion Paper. No. 501, DIW.

Minniti, M. and Langowitz, N. 2007. "The entrepreneurial propensity of women". Entrepreneurship Theory and Practice 31 (3): 341-364.

Minniti, M. and Nardone, C. 2007. "Being in someone else's shoes: gender and nascent entrepreneurship". Small Business Economics Journal 28 (2-3): 223-239.
Minniti, M., Arenius, P. and Langowitz, N. 2005. Global Entrepreneurship Monitoring: 2004 Report On Women and Entrepreneurship. London: Centre for Woman's Leadership at Babson College/London Business School.

Noorderhaven N.G., Thurik A. R, Wennekers A.R.M., Van Stel, A. J. 2004. "The role of dissatisfaction and per capita income in explaining selfemployment across 15 European countries". Entrepreneurship: Theory and Practice 28 (5): 447-466.

OECD 1998. Fostering Entrepreneurship. The OECD Jobs Strategy. Paris: OECD.

Parker, S.C. and Robson, M.T. 2004. "Explaining international variations in entrepreneurship: Evidence from a panel of OECD Countries". Southern Economic Journal 71 (2): 287-301.

Reynolds, P., Bygrave, B. and Autio, E. 2003. GEM 2003 Executive Report. London: Babson College, London Business School: E. M. Kauffman Foundation.

Reynolds, P. D., Hay, M. and Camp, S. M. 1999. Global Entrepreneurship Monitoring: 1999 Executive Report, London: Babson College, London Business School and Kauffman Center for Entrepreneurship Leadership

Shane, S. 2000. "Prior knowledge and the discovery of entrepreneurial opportunities". Organization Science 11 (4), 448-469.

Shaver, K. G. and Scott, L. R. 1991. "Person, process, choice: the psychology of new venture creation". Entrepreneurship: Theory and Practice 16 (2): 23-45.

Shane, S. and Venkataraman, S. 2000. "The promise of entrepreneurship as a field of research". Academy of Management Review 25: $217-226$.

Shapiro, A. and Sokol, L., 1982. "The social dimension of entrepreneurship". In Encyclopaedia of Entrepreneurship, edited by D. L. Kent and K. H. Vesper. Englewood Cliffs, NJ: Prentice-Hall.

Sternberg R. 2005. "Business start-ups: Hope for regional development in Germany".

http://www.difu.de/publikationen/dfk/en/05_1/05_1_sternberg.pdf (accessed July 21, 2007)

Sternberg, R, Wennekers, S. 2005. "Determinants and effects of new business creation using global entrepreneur-ship monitor data". Small Business Economics 24 (3): 193-203.

Tajnikar, M. and Pušnik, K. 2008. "Determinants of entrepreneurship in Slovenia from an international perspective". In Advances in entrepreneurship research, edited by C. A. Veloutsou, 19-31. Athens: Athens Institute for Education and Research.

Thanassoulis, E., Portela, M. C. S., and Despić, O. 2008. "Data envelopment analysis: The mathematical programming approach to efficiency analysis". In The Measurement of Productive Efficiency and Productivity Growth, edited by V. H. O. Fried, C. A. K. Lovell and S. S. Schmidt, 251-420. Oxford: Oxford University press.

Thurik, R. and Grilo, I. 2005. "Determinants of entrepreneurship engagement levels in Europe and the U.S. Papers on Entrepreneurship". Growth and Public Policy, 03 - 2005, Max Planck Institute of Economics.

Tominc, P. and Rebernik, M. 2006. "Female entrepreneurship growth aspirations in Slovenia: an unexploited resource". In Growth-Oriented Women Entrepreneurs and Their Businesses: A Global Research Perspective, New Horizons in Entrepreneurship, edited by C.G. Brush, N.M. Carter, E. Gatewood, P. G. Greene, and M. M. Hart. Cheltenham, UK, Northampton, MA, U.S.: E. Elgar.

Uhlaner, L. and Thurik, A. R. 2004. "Post-Materialism: A cultural factor influencing total entrepreneurial activity across nations". Papers on Entrepreneurship, Growth and Public Policy 07 - 2004, Max Planck Institute of Economics.

Verheul, I., Wennekers, S., Audretsch, D. and Thurik, R. 2002. "An eclectic theory of entrepreneurship: Policies, institutions and culture". In Entrepreneurship: Determinants and Policy in a European-US Comparison, 
edited by D. B. Audretsch, A. R. Thurik, I. Verheul and A. R. M. Wennekers. Boston/Dordrecht: Kluwer Academic Publisher.

Wagner, J. 2003. "Testing Lazear's Jack-Of-All-Trades view of entrepreneurship with German micro data". Applied Economics Letters 10: 687 - 689.

Wennekers, A. R. M., Uhlaner, L. and Thurik, A. R. 2002. "Entrepreneurship and its conditions: A macro perspective". International Journal of Entrepreneurship Education 1 (1): 25 - 64.

Wit, G. de and van Winden, F. A. A. M. 1989. "An empirical analysis of self-employment in the Netherlands". Small Business Economics 1 (4): 263-284.

Zhu, J. 2003. Quantitative Models for Performance Evaluation and Benchmarking. Data Envelopment Analysis with Spreadsheets and DEA Excel Solver, Boston: Kluwer Academic Publishers. 